\title{
SPRAWOZDANIE Z DZIALALNOŚCI \\ WYŻSZEGO SEMINARIUM DUCHOWNEGO W SANDOMIERZU W ROKU AKADEMICKIM 2020/2021
}

Mijający rok akademicki 2020/2021 wspólnota Wyższego Seminarium Duchownego w Sandomierzu przeżywała jako jubileuszowy. Dokładnie 200 lat temu, 7 listopada 1820 r., zainaugurowano pierwszy rok akademicki w sandomierskiej uczelni duchownej. $Z$ tej racji Penitencjaria Apostolska udzieliła odpustu zupełnego za modlitwę i nawiedzenie kościoła seminaryjnego pw. św. Michała Archanioła (m.in. w czasie codziennej adoracji Najświętszego Sakramentu od godz. 19.00 do 21.00).

$\mathrm{W}$ omawianym roku akademickim studia w seminarium podjęło czterech nowych kandydatów do kapłaństwa, którzy swoją formację rozpoczęli 1 września 2020 r. tzw. okresem propedeutycznym. Celem czasu przygotowawczego jest pogłębienie wiary młodych kandydatów, zapoznanie ich z życiem wspólnoty seminaryjnej oraz z różnymi zagadnieniami związanymi z funkcjonowaniem Kościoła powszechnego. W tym okresie udali się oni również na wyjazd integracyjny w Bieszczady, do ośrodka Caritas w Nasicznem. Na początku roku sprawozdawczego do kapłaństwa przygotowywało się 33 alumnów. Pierwszy rocznik zasiliło czterech wspomnianych już adeptów, na roku drugim studiowało trzech alumnów, na roku trzecim - czterech, na czwartym - również czterech, na piątym - dwunastu, na szóstym zaś - sześciu studentów.

\section{Kadra wychowawczo-naukowa}

Pracą formacyjną w minionym roku akademickim kierował Zarząd Seminaryjny, w skład którego wchodził rektor - ks. dr Rafał Kułaga, a także prefekt - ks. mgr Piotr Przysucha. Nad formacją duchową czuwali ojcowie duchowni: ks. dr Rafał Kobiałka i ks. mgr Szymon Brodowski. Funkcję dyrektora administracyjnego pełnił ks. mgr Stanisław Tylus. Ojców duchownych w sprawowaniu sakramentu pokuty i pojednania wspierał swoją posługą ks. mgr Marek Kuliński.

Do wykładowców należeli: ks. dr Jan Biedroń, ks. dr Marcin Biegas, ks. mgr Leszek Chamerski, ks. dr Tomasz Cuber, ks. dr Jerzy Dąbek, ks. dr Michał Grochowina, ks. dr Roman Janiec, ks. prof. dr hab. Zdzisław Janiec, ks. dr Krzysztof Kida, ks. dr Rafał Kobiałka, s. dr Maria Konopka, ks. dr Adam Kopeć, ks. dr Marek Kozera, ks. dr Bartłomiej Krzos, ks. dr Rafał Kułaga, ks. dr Marek Kumór, ks. dr Paweł Lasek, ks. mgr lic. Tomasz Lis, ks. dr hab. Jacek Łapiński, prof. KUL, ks. dr Jacek Marchewka, mgr Izabela Marciniak, ks. dr hab. Tomasz Moskal, prof. KUL, mgr Witold Nowakowski, ks. dr Waldemar Olech, mgr Agnieszka Pierzchała, ks. dr 
Witold Płaza, ks. dr Dariusz Sidor, ks. dr hab. Leon Siwecki, prof. KUL, dr Beata Skrzydlewska, ks. dr Piotr Tylec oraz ks. mgr Adam Warchoł. Profesorowie prowadzili zajęcia dydaktyczne również poza seminarium, m.in. na Katolickim Uniwersytecie Lubelskim Jana Pawła II w Lublinie. Podejmowali także działalność na rzecz Kurii Diecezjalnej w Sandomierzu, miejscowego Sądu Biskupiego oraz na licznych odcinkach działalności duszpasterskiej w diecezji sandomierskiej.

\section{Formacja seminaryjna}

\section{Formacja ludzka}

Formację ludzką realizowano zarówno poprzez rozmowy indywidualne, jak i spotkania wychowawców z poszczególnymi rocznikami alumnów oraz z całym alumnatem. Przełożeni chcieli dzięki temu ukształtować w alumnach postawę i osobowość przyszłych kapłanów. Wskazywano więc na potrzebę ciągłej pracy nad sobą celem wypracowania takich cech osobowości, jak prawość, uczciwość i wzajemny szacunek. Miało temu służyć także podjęcie przez alumnów działalności apostolskiej na terenie Sandomierza i szerszym w czasie kilku wyjazdów związanych z funkcjonowaniem kół apostolatu, m.in. Koła Misyjnego, Caritas, KSM, harcerstwa, krwiodawstwa, grupy „Pro Life” czy oazy Ruchu Światło-Życie. Alumni uczestniczyli również w życiu kulturalnym, biorąc udział w sympozjach, spotkaniach, zawodach sportowych i innych tego typu wydarzeniach.

\section{Formacja duchowa}

Podstawę tej formacji stanowiły codzienne ćwiczenia duchowe w kaplicy seminaryjnej skoncentrowane wokół Eucharystii oraz indywidualna praca $\mathrm{z}$ ojcami duchownymi. W budowaniu duchowości pomagała regularna spowiedź, adoracja Najświętszego Sakramentu, medytacja, lektura duchowa, modlitwa różańcowa i koronka do Bożego Miłosierdzia.

W roku akademickim 2020/2021 odbywały się również dni skupienia, które prowadzili ojcowie duchowni oraz ks. Paweł Goliński, ks. Augustyn Łyko i ks. Charles Tanke. Szczególnym czasem dla alumnów były rekolekcje. Jesiennym ćwiczeniom rekolekcyjnym trwającym od 21 do 24 października $2020 \mathrm{r}$. przewodniczył ks. Grzegorz Lipiec, ojciec duchowny z Seminarium Duchownego w Radomiu. Po tych rekolekcjach ks. bp dr Edward Frankowski poświęcił strój duchowny czterem alumnom z trzeciego kursu, udzielił dwóch posług akolitatu oraz przyjął do grona kandydatów do święceń diakonatu i prezbiteratu dziesięciu kleryków z kursu piątego. Rekolekcje wielkopostne, które odbyły się w dniach od 21 do 25 lutego 2021 r., wygłosił ks. prof. dr hab. Piotr Mazurkiewicz. Na zakończenie tego czasu bp dr Krzysztof Nitkiewicz udzielił posługi lektoratu i akolitami klerykom trzeciego i czwartego kursu. Oddzielne rekolekcje przeżywali alum- 
ni roku piątego przed przyjęciem święceń diakonatu oraz diakoni roku szóstego przed święceniami prezbiteratu. Święcenia diakonatu odbyły się 28 maja w dwóch miejscach: w kościele parafialnym w Nowosielcu (bp Frankowski) oraz kolegiacie św. Michała w Ostrowcu Świętokrzyskim (bp Nitkiewicz). Natomiast święceń kapłańskich w sandomierskiej katedrze 19 czerwca udzielił pięciu diakonom bp Krzysztof Nitkiewicz, ordynariusz diecezji sandomierskiej.

W roku sprawozdawczym odbyła się pielgrzymka do Sanktuarium Matki Bożej Saletyńskiej w Dębowcu oraz Sanktuarium św. Jana z Dukli. Zorganizowano ją 27 września na rozpoczęcie okresu formacyjnego. Formacji duchowej alumnów służył udział w niektórych celebracjach liturgicznych w sandomierskiej katedrze, jak np. trzecia rocznica śmierci biskupa seniora diecezji sandomierskiej, Wacława Świerzawskiego (7 października 2020 r.); uroczystości ku czci patrona miasta, bł. Wincentego Kadłubka (11 października); Msza Święta za zmarłych biskupów, kapłanów i osoby konsekrowane (2 listopada) oraz uroczysta Msza Święta z okazji 100. rocznicy odzyskania przez Polskę niepodległości (11 listopada).

Miejsce duchowego formowania alumnów stanowił też kościół seminaryjny pw. św. Michała Archanioła. Wspólnota WSD w Sandomierzu uczestniczyła tam w wielu uroczystych wydarzeniach, jak np. uroczystości odpustowe ku czci św. Michała Archanioła, którym przewodniczył dotychczasowy dyrektor administracyjny, ks. Dominik Bucki (29 września 2020 r.), Msza Święta inaugurująca 201. rok akademicki, której głównym celebransem był abp Stanisław Budzik, metropolita lubelski, wzięli w niej udział również: abp Wacław Depo, metropolita częstochowski, oraz bp Piotr Turzyński, sufragan radomski (8 października); uroczystości w jubileuszową rocznicę erygowania seminarium - Msza Święta pod przewodnictwem bp. Krzysztofa Nitkiewicza wraz z papieskim błogosławieństwem, transmitowana przez Radio Kielce (7 listopada); Msza Święta za zmarłych rektorów, profesorów, wychowawców, alumnów, siostry zakonne i pracowników świeckich seminarium (26 listopada), Msza Święta ku czci Patronki seminarium, Matki Bożej Niepokalanej (8 grudnia), modlitwy w intencji beatyfikacji sługi Bożego ks. Wincentego Granata (11 grudnia), obchody ku czci św. Tomasza z Akwinu (28 stycznia 2021 r.), Msza Święta z racji uroczystości św. Józefa oraz zawierzenie wspólnoty seminaryjnej temuż świętemu (19 marca), a także jubileusz 25. rocznicy święceń księdza rektora Rafała Kułagi (1 czerwca).

Formacji duchowej kleryków służyły również celebracje liturgiczne na terenie Sandomierza oraz diecezji: uroczystości odpustowe w sandomierskiej parafii św. Józefa (4 października 2020 r.), święcenia kapłańskie diakona Piotra Sosnówki w kościele pw. św. Franciszka Salezego i św. Andrzeja Boboli w Gorzycach, których udzielił bp Krzysztof Nitkiewicz (8 listopada), Msza Święta z racji Światowego Dnia Ubogich w kościele pw. Świętego Ducha w Sandomierzu (17 listopada), uroczystości Bożego Ciała na terenie miasta wraz z procesją z kościoła pw. Podwyższenia Krzyża Świętego do świątyni seminaryjnej (3 czerwca 2021 r.). 


\section{Formacja intelektualna}

Formacja ta przejawiała się przede wszystkim w systematycznej pracy w ramach wykładów oraz ćwiczeń prowadzonych według ratio studiorum. Oprócz tego alumni mieli okazję rozwijania swoich zainteresowań naukowe, biorąc udział w różnych sympozjach, czy to indywidualnie, czy też wraz z całą wspólnotą. Ponadto program studiów w WSD w Sandomierzu obejmował liczne wykłady, ćwiczenia i konwersatoria, wyniki zaś nauczania były weryfikowane przez kolokwia, zaliczenia i egzaminy. Alumni przygotowywali się do nich podczas studium indywidualnego wpisanego w program dnia. Wszyscy alumni uczęszczali na zajęcia z języka angielskiego. Dodatkowo prowadzono też lektoraty z języka włoskiego i francuskiego oraz języka migowego. Zwieńczenie formacji naukowej w ramach studiów teologiczno-filozoficznych stanowiła obrona prac magisterskich diakonów. Trzech diakonów pozytywnie przedstawiło swoje prace magisterskie na Katolickim Uniwersytecie Lubelskim, wieńcząc tym samym swoje studia w domu formacyjno-dydaktycznym. Przed obroną zdali egzaminy absolutoryjne z Pisma Świętego, teologii dogmatycznej, teologii moralnej oraz prawa kanonicznego. Ponadto alumni piątego roku i diakoni z rocznika szóstego w ramach praktyk katechetycznych prowadzili katechezy w szkołach Sandomierza. Dodatkowo alumni, pisząc i redagując artykuły, wydali jeden numer czasopisma „Powołanie”, co dało im możliwość rozwinięcia w ten sposób swoich zdolności i talentów.

\section{Formacja duszpasterska}

Formacja duszpasterska przebiegała na wielu płaszczyznach zarówno podczas trwania roku akademickiego, jak i w czasie praktyk wakacyjnych oraz przerw świątecznych. Podobnie jak w latach ubiegłych w ramach formacji duszpasterskiej alumni pełnili na wakacjach liczne posługi: po pierwszym i drugim roku pracowali jako przewodnicy w bazylice katedralnej i w kościele seminaryjnym, po roku trzecim i czwartym - pełnili funkcję animatorów podczas rekolekcji oazowych, po roku piątym - głosili homilie w kościele seminaryjnym.

Ważną inicjatywą dla wspólnoty seminaryjnej była diecezjalna sztafeta modlitw o powołania, którą 25 kwietnia 1921 r. rozpoczął bp Krzysztof Nitkiewicz. Przez miesiąc księża profesorowie wraz z alumnami wyjeżdżali do parafii diecezji sandomierskiej, aby wspólnie z wiernymi modlić się o nowe powołania kapłańskie, zakonne i misyjne.

Alumni przygotowywali akademie i przedstawienia, które prezentowali przed szerszym gronem odbiorców, np. klerycy z drugiego roku przygotowali przedstawienie z okazji dnia św. Mikołaja (6 grudnia 2020 r.). W minionym roku akademickim w ramach czynnego apostolatu alumni podejmowali również posługę w kaplicy Domu Opieki Społecznej w Sandomierzu, a także posługiwali jako szafarze Najświętszego Sakramentu w sandomierskim szpitalu. Poza tym odwiedzali chorych w domach, kapłanów mieszkających w Domu Księży Emerytów, czynnie udzielali 
się podczas praktyk w Domu Pomocy Środowiskowej w Sandomierzu, w ramach praktyk brali udział w pracach ośrodka „Radość Życia” prowadzonego przez Caritas Diecezji Sandomierskiej.

Zwyczajna forma praktyki duszpasterskiej polegała na codziennej posłudze alumnów w kościele seminaryjnym. Alumni mogli sprawdzić swoje umiejętności i zdobyć nowe doświadczenia przez posługę kaznodziejską. W ramach praktyk alumni z piątego roku głosili próbne kazania w kościele św. Michała Archanioła.

Ważne miejsce we wspólnocie WSD w Sandomierzu pełnił chór kleryków, który uświetniał swoim śpiewem liczne spotkania i uroczystości, prowadzony przez ks. mgr. Leszka Chamerskiego.

\section{Sprawy administracyjno-gospodarcze}

Budynek Wyższego Seminarium Duchownego należy do wyróżniających się zabytków miasta, sięga swymi początkami XVII w. Wspólnota seminaryjna dokładała wszelkich starań, aby jej dom był utrzymany w należytym stanie. W minionym roku akademickim kontynuowano prace konserwatorskie w kościele pw. św. Michała Archanioła (m.in. ukończono następny etap odnawiania zabytkowej ambony). Ponadto wykonywano prace bieżące konieczne dla funkcjonowania budynku.

Za możliwość realizacji prac na tylu odcinkach życia seminaryjnego należy podziękować najpierw Panu Bogu, a następnie ludziom. Wspólnota seminaryjna pragnie, by prace te zostały dobrze wykorzystane na większą chwałę Stwórcy i dla zbawienia ludzi, jak również ku stałemu budowaniu jedności tych, którzy tutaj mieszkają. 